International Journal of Civil Engineering and Technology (IJCIET)

Volume 9, Issue 7, July 2018, pp. 1575-15780, Article ID: IJCIET_09_07_168

Available online at http://www.iaeme.com/ijciet/issues.asp?JType=IJCIET\&VType=9\&IType=7

ISSN Print: 0976-6308 and ISSN Online: 0976-6316

(C) IAEME Publication

Scopus Indexed

\title{
AN EFFECT PHENOMENA CIRCLE LIVING FIELD IN SECANGGANG LANGKAT
}

\author{
Triono Eddy \\ Lecturer at Law, Postgraduate Program, \\ Universitas Muhammadiyah Sumatera Utara
}

\author{
Bhakti Alamsyah, Solly Aryza, Andysah Putera Utama Siahaan \\ Universitas Pembangunan Panca Budi Medan, Indonesia
}

\begin{abstract}
Fisherman's life is generally synonymous with poverty, this can be seen from the slum state of residence and the houses of a waterless stage and poor health environment and the low education of the fishermen. The problems of this research are. a. How is the life of fishermen in Secanggang village Langkat, $b$. how the government's role in tackling the life of fishermen in a cleavage $c$. What should the government do for the future of fishermen in Secanggang village langkat. This research is a juridical descriptive whose data source is done by field research and documentation, data collecting is done by interview, quieter, observation, research result, fisherman at Secanggang village Langkat still using traditional fishing gear and 35\% fishermen do not have fishing facilities especially bots, fishermen live depending on weather and natural conditions, and sea waves, to sustain family life the fishermen have to borrow money at collector which will be paid later with the catch of the fish. The children in Secanggang village Langkat do not criticize education because they prefer to catch fish and get money and the children just finish junior high school to continue to high school is very difficult because of unfavorable economic conditions and transportation costs are quite high.
\end{abstract}

Key words: Phenomenon, Circle, Life, Fisherman.

Cite this Article: Triono Eddy, Bhakti Alamsyah, Solly Aryza and Andysah Putera Utama Siahaan, An Effect Phenomena Circle Living Field In Secanggang Langkat, International Journal of Civil Engineering and Technology, 9(7), 2018, pp. 1575-15780. http://www.iaeme.com/ijciet/issues.asp?JType=IJCIET\&VType=9\&IType=7

\section{INTRODUCTIONS}

Indonesia is a country with huge sea potential, has a vast sea area of about $5.800 .000 \mathrm{~km} 2$ which are located between the cross position between two Pacific oceans with the number of 17,508 islands are rich in flora and fauna. Fisheries is one source of state assets that are useful in improving the welfare of Indonesian society [1]. 
Fishermen depend on life by managing the potential of marine resources. The work of fishermen is hereditary and has not changed much. The poverty rate in Indonesia is still dominated by the fishermen community, until March 2015 the poor in Indonesia is 28.59 million people or $11.2 \%$ of the total population of Indonesia of which $32.4 \%$ are fishermen [2]

\section{LITERATURE REVIEW}

Fishermen must have the ability to work in addition to being fishermen because the famine season is sure to come every year and the old cannot be ascertained, the sea does not provide a routine guarantee because it depends on the nature so difficult to cover the needs of fishermen's household life [3].

In tackling the life of the household to the community in Secanggang village Langkat there is a good cooperation between husband and wife, the wife is a very active role in tackling family life, the wife awaits the arrival of her husband from the sea and the fish catch is sold by his wife [4].

There is also the wife of the fisherman who works in the statue. Fishermen in Secanggang village Langkat also involve their children in some activities to earn a living, for the boys will follow the parents or relatives to find fish at sea or clean the boat that had just arrived at sea.

Girls help the mother to make salted fish from cleansing and drying fish. This is usually done to overcome the cost of domestic life during the famine because the work of the fisherman is very dependent on the nature of the children then split the fish shell and then sliced thinly and in the drying, fish purchased from the boat in the boat $\mathrm{Rp} 2500 / \mathrm{kg}$, shellfish which weighs $10 \mathrm{~kg}$ to $2 \mathrm{~kg}$ of this fish will be sold with collector with price Rp 60.000 / kg [5].

In terms of ownership of fishing equipment in Secanggang village, Langkat fishing is divided into 2 parts namely

a. Fishermen with trawlers and fishing boots

b. Fishermen who have trawls but do not have fishing bots. This fisherman runs his profession by renting fishing boots from toke which consequently he must sell his fish to the owner of a fish bot [6].

The results of interviews with Mr. Didit each went to the sea only Rp 100,000 because he does not have a bot, sometimes only once a week he can go to sea this depends on the situation of natural conditions [7].

Every morning the mothers and children work to catch shrimp and shellfish and they come home at 11 noon because it has rising tide. The children in Sicanggang Langkat are $60 \%$ not educated, the reason is not going to school because it is better looking for fish and money that can be used for snacking, eating and smoking.

The lifestyle habits of the fishermen everywhere are almost the same that is very consumptive if the abundant income they will buy anything and never think of tomorrow if less money to borrow the same collector or skipper.

In Secanggang village Langkat the reason the children are not in school because of the economic situation of $47 \%$ and $37 \%$ did not want to go to school, because the school has no money and cannot snack and smoke and $16 \%$ say it is useless because graduated from high school there is no employment in land be forced to go to sea too, Secanggang village Langkat fishermen community in one family has 2 or 4 children, of course, income from the fisherman is not sufficient family needs.

The result of the research interview with Andi a student, that only anak2 fisherman who level of economic life that is just settled education, because the cost to go one way from Secanggang village Langkat it Rp 10.000 per person with bot with capacity of 10 passengers, 
therefore fishermen who stay in school stay outside Secanggang Langkat because transportation costs for commute is very high.

In general, Secanggang village Langkat children who live in pesantren whose food costs Rp 500.000 per month and tuition fee Rp 450,000 per month and other money Rp 300.000 So a fisherman must prepare money as much as Rp 1.250.000 per month for a student, so economic factor that is very important to lead the next generation of the nation does not taste education in the fine web.

Only $25 \%$ of children in Secanggang village Langkat enjoy high school and faculty education so for the future the Government should have a program to establish some schools, because in Secanggang village Langkat there is only one elementary school and one sanawiyah is no high school, therefore the government is expected in terms of this must have a program by looking at what is the needs of the fishing community because the need is very different from one fisherman location to another fisherman location means that the program is not universal which has been determined by the government [8].

The government is expected to establish a primary school, junior high school, and senior high school so that the next generation of Secanggang village Langkat can be educated because only with education is the most powerful way to cut out of the poverty cycle [9].

\section{METHODE OF RESEARCH.}

This research is a descriptive research that sourced from primary and secondary data obtained by observation and interview, the respondents in this research are 50 fishermen, and some informants 1 headmaster, 2 urban village staff 2 midwives, 1 skipper which the result can give a description of the life of the fisherman in SiCanggang village Langkat.

\subsection{Infrastructure and Facilities.}

Secanggang village Langkat community already has electricity as a lighting device of PLN and for clean water needs every day there are 4 drilling wells sold in the community for Rp 4000 / drum, the results of interviews with Adit's mother he only needs 5 water drums for five days with 4 family members and this is piped directly to residents' homes and at present there are government programs for PDAMs in the region with the condition that a new installation transaction is charged $\mathrm{Rp} 800,000$.

The fishermen also already have electronic devices rice cooker, refrigerator, hand pond and even the style of his life has been imitating the city people in general, the young people are familiar with hair dye and good clothes and women are already wearing lipstick and baby children already wear pampers.

There is no other transport in Secanggang except bots with a capacity of 20 people, which cost Rp 10,000 once traveling from Batang Buluh. Any activity to something is done on foot, but there is a collector who rent out 4 units of Honda that is small size unlike the usual size similar to children's game which rent money is Rp.10.000 / jam which is used by entrants to surround the village Secanggang.

The streets of Secangang Langkat are small and small roads already built by the government, so the residents no longer walk on the wooden tread that is prone to collapse.

Most of the people's homes are under a house, and some are half-permanent, the land is owned by the government and every year the fishermen have to pay the government $\mathrm{Rp}$ $3,600.00 /$ year as the tax of the land use is obtained from the levies on the fishermen community.

Although the government has issued Government Regulation No. 75 of 2015 on Non-Tax State Revenue (PNBP) of Marine and Fisheries, it still does not apply to fishermen in 
Secanggang village Langkat. Until now even though there is already a new ministry Susi Puji Astuti there is no regulation in favor of the survival of traditional fisherman's life, even they are often disturbed by trawler fishermen who come from Belawan.

Despite the existence of Law No. 31 of 2004 which provides a decent life insurance for fishermen but this has not been touched from the fishermen community in Secanggang village.

The government also provides rice body of logistic affairs to the people who buy Rp 15.000 $15 \mathrm{~kg}$ for the community and this is only done once a month or twice, but at the time the researcher conducted this research, almost 3 months of rice donation did not enter the fishing village Secanggang Langkat.

The government has also established one Puskesmas whose medical personnel are only 2 nurses and doctors are not available, doctors are only sent once every six months to check public health for free. The fishermen community is not very fond of going to the Puskesmas because it is very expensive, the researcher observed in the field of a mother with diabetes eruption and both legs have holes and unable to walk again so that the nurse who visited the patient home and give medicine and replace the bandage once inside 2 days and the patient has to pay the cost of treatment Rp. 500.000 / week, and the public if sick most of the treatment to a shaman or smart people on the grounds of low cost. In this case the government must create a program in order to support the health care of these fishermen by making poor health cards or whatever the purpose, so that fisherman fishermen can use free health service, is not paid because only in a healthy body there is a healthy soul and only healthy people can contribute to the family and the surrounding community.

If viewed around the fisherman's house scattered rubbish here and there, according to Halizah mother there is no desire of the community to clean up or trying to provide a garbage can collect to look a regular and healthy environment, people reasoned it is not necessary because the garbage will carry water sea tide.

In the sicanggang village, there is no fish auction place (TPI) so only tokeh2lah who buy fishing results, of course with a cheap price for the future, the government should have a program to provide soft loans to the fishing communities. Because what is owned by the fishermen either in the form of fishing tools cannot be used as collateral for debt in the Bank, because banks provide credit should be based on collateral from the debtor.

\subsection{Traditional Ceremony for Fishermen of Langkat}

Fishermen in Secanggang village Langkat are very vulnerable to marine dangers, therefore people have a belief so that they are always protected, healthy and far from danger hence must be performed marine herbal ceremony performed by sea handler which is usually performed once a year with the period of abstinence 3 days.

This ceremony is performed by eating with all the villagers of Secanggang village Langkat and slaughtered are some goats as their side dish and a certain portion dedicated to supernatural beings who control the sea and fruits are also various kinds of cakes made by mothers in SiCanggang village Langkat.

Although the people in Secanggang village Langkat are all Muslims they continue to worship the spirits that control the sea so that they avoid danger and the fishermen survive to go to sea and get a lot of seas.

The ceremony was led by a sea handler, but now it has been interpreted as a thanksgiving and thanks for the fishermen given the sea and health products and away from the disease. This event is followed by prayers and offerings

After the meal together, the community is as holy as coming out of the Secanggang village Langkat area in droves with the whole family, fearing that their children should not break the 
taboos such as fighting, throwing, saying dirty and citing something that may cause anger the sea guard.

Anyone who has gone out of the village should not go back for 2 days. Each family went to meet and live with relatives outside the village Secanggang village langkat, According to Ubin they are living with relatives in Binjei, Stabat, Tanjung Pura and Medan to avoid do not get his family hit by reinforcements because many of the restrictions that apply to the implementation of the ceremony reject the reinforcements, so the village sicanggang village Langkat is lonely and becomes a dead village with no occupants.

\section{RESEARCH RESULTS AND DISCUSSION}

Secanggang village Langkat community consists of 800 families who work as fishermen and a small number of grocery sellers. The community here has a very high tolerance because the village head of a village is a Nias tribe, while the people are mostly Malay people who are all Muslims.

Community fishermen community in Secanggang village Langkat if viewed from several aspects namely:

a. In terms of livelihoods are those whose all life activities related to the sea and coastal or those who make fisheries as the eyes of seekers.

b. In terms of the way of life of the community of fishermen is mutual help and help, it is very important in tackling something that requires a very large cost or requires a large amount of energy for example in setting up a house or wave pendulum around the village to do any party whether it is a marriage, circumcision.

c. Greened in terms of skills, fishermen are heavy workers but they have very simple skills. His profession at sea was passed down by parents

In terms of the social structure that fishermen in the smooth Jarring is composed of a homogeneous community, usually, fishermen using traditional fishing equipment is very simple so that productivity is also very small. this very remote fishing village whose means of transportation is only a canoe.

- Transportation cost from Batang Buluh Rp 10,000 once a day. In general, there are two versions of how the fishermen in the fine Jarring went to sea

With a small boat, which is 1 ton, they are 2 people and catch fish with a net. The fishermen start to sea at $5 \mathrm{pm}$ and return home at 10 am which on average each sea removal costs as much as Rp. 100.000 per day that is to diesel and cigarette.

Ordinary fish catches are shrimp kelong, shrimp ijo that cost Rp $100.000 / \mathrm{kg}$ and small fish. The average fishing result is $\mathrm{Rp} 200,000$ / day

- Using a boat with engine power of 5 to 12 horsepower and sailing 3 miles on the beach and able to go to sea three days, commonly called a net cooling according to the results of interviews Amat the sea boss said the cost to go to sea one way: Rp 250,000 for oil and Rp 150,000 for the supply of the sea including food supplies. Fish obtained usually large fish and large, such as pomfret, gerapuh fish.

\section{CONCLUSIONS}

a. Fishermen in the sicanggang village are still using traditional fishing gear, of course, the results are certainly very limited to change the economic level of these fishermen, the government should try to provide assistance in the form of jingring Coming by way of payment of installments 
b. The government in providing assistance should observe directly to fishermen what is a very urgent need for the community, so it is not based on a comprehensive program because the needs of fishermen in the village are different from the needs of other fishing villages.

c. The government must create human resource capacity especially in the field of education by establishing schools, in order to be able to break the poverty chain as quickly as possible, and the need for socialization for parents of fishermen by giving an understanding of education is one way to decide the poverty of the fishing community.

\section{REFERENCES}

[1] M. Parasol, "The impact of China's 2016 Cyber Security Law on foreign technology firms, and on China's big data and Smart City dreams," Comput. Law Secur. Rev., vol. 34, no. 1, pp. 175-179, 2018.

[2] S. Aryza, M. Irwanto, Z. Lubis, A. P. U. Siahaan, R. Rahim, and M. Furqan, “A Novelty Design Of Minimization Of Electrical Losses In A Vector Controlled Induction Machine Drive,” IOP Conf. Ser. Mater. Sci. Eng., vol. 300, no. 1, p. 12067, 2018.

[3] A. H. Lubis, "ICT Usage Amongst Lecturers and Its Impact Towards Learning Process Quality," vol. 34, no. 1, pp. 284-299, 2018.

[4] H. Aspan, I. M. Sipayung, A. P. Muharrami, and H. M. Ritonga, "The Effect of Halal Label, Halal Awarness, Product Price, and Brand Image to the Purchasing Decision on Cosmetic Products (Case Study on Consumers of Sari Ayu Martha Tilaar in Binjai City)," Int. J. Glob. Sustain., vol. 1, no. 1, p. 55, 2017.

[5] N. S. Ristianti, "Pengembangan Konsep Wisata Apung Kampung Nelayan Pesisir Balikpapan," Jurnalruang, vol. 1, no. 1, pp. 31-40, 2015.

[6] solly Aryza, "A Novelty Design Of Minimization Of Electrical Losses In A Vector Controlled Induction Machine Drive," Scopus, no. 1, p. 20155, 2017.

[7] A. P. U. Siahaan, S. Aryza, R. Rahim, and A. H. Lubis, "Comparison Between Dynamic And Static Blocks In Sequitur Algorithm,” IOSR J. Comput. Eng., vol. 19, no. 04, pp. 3943, 2017.

[8] R. K. Goyal and S. Kaushal, "Effect of utility based functions on fuzzy-AHP based network selection in heterogenous wireless networks," 2015 2nd Int. Conf. Recent Adv. Eng. Comput. Sci. RAECS 2015, no. December, pp. 0-4, 2016.

[9] H. Umar, "Government Financial Management Strategy for Preventing Corruption in Indonesia," South East Asian J. Manag., vol. 5, no. 2, pp. 19-36, 2011. 